доктор ист. наук, профессор, ведущий научный сотрудник Отдела социально-политических исследований Института истории, археологии и этнографии народов Дальнего Востока ДВО РАН (г. Владивосток).

Электронная почта: dudarenoksv@ gmail.com

\title{
Институту истории, археологии и этнографии народов Дальнего Востока ДВО РАН - 50 лет!
}

DOI https://doi.org/10.24866/2542-1611/2021-2/6-21

Первого июля 2021 г. Институт истории, археологии и этнографии народов Дальнего Востока ДВО РАН отметил пятидесятилетие! Создание и становление института пришлось на весьма примечательное время для российского Дальнего Востока: шёл процесс интенсивного освоения природных ресурсов региона, создавались новые промышленные предприятия, вузы, обновлялись дальневосточные города, росло население. Росло идеологическое и военное противостояние двух «сверхдержав», резко обострились отношения между СССР и Китаем. В этих условиях возрастала роль гуманитарной и идеологической составляющей общественной жизни региона, которую и должна была формировать историческая наука [16, с. 5].

Решение об организации во Владивостоке Института истории, археологии и этнографии народов Дальнего Востока было приято Президиумом АН СССР 26 ноября 1970 г. Менее чем через год, 1 июля 1971 г., на базе существовавшего с 1954 г. в Дальневосточном филиале им. В. Л. Комарова СО АН СССР небольшого Отдела истории и археологии был создан ИИАЭ. Его первым и бессменным руководителем на протяжении 20 лет был академик АН СССР Андрей Иванович Крушанов (1921-1991).

Именно его усилиями Институт истории стал признанным в стране центром дальневосточной исторической науки.

А. И. Крушанов вёл огромную редакторскую работу: под его редакцией вышли в свет десятки монографий, коллективных трудов и научно-популярных изданий. Под его руководством началась работа над фундаментальными коллективными трудами Института - «Историей Дальнего Востока», «Историей Северо-Восточного Китая», историко-этнографической серией «История и культура народов Дальнего Востока» и др.

А. И. Крушанов - основатель научной школы «Комплексного анализа регионального исторического процесса». При нём активизировалась подготовка научных кадров для всего Дальнего Востока через аспирантуру, в том числе целевую. Андрей Иванович дал путёвку в «большую науку» многим учёным и преподавателям высшей школы: под его руководством подготовлено 8 докторских и 60 кандидатских диссертаций.

Для иитирования:

Дударёнок С. М. Институту истории, археологии и этнографии народов Дальнего Востока ДВО РАН - 50 лет! // Известия Восточного института. 2021. № 2 . C. 6-21. DOI https://doi. org/10.24866/2542-1611/2021 $2 / 6-21$ Его ученики работают не только в ИИАЭ, но и практически в каждом вузе Дальнего Востока, определяя лицо исторической науки Дальневосточного региона.

В память об А. И. Крушанове, крупном учёном, патриоте Дальнего Востока, названы одна из улиц г. Владивостока, а также средняя общеобразовательная школа в с. Михайловка Михайловского района Приморского края, директором кото- 
рой он был после службы в армии - (МБОУ СОШ им. А. И. Крушанова с. Михайловка). В ДВО РАН учреждена премия им. А. И. Крушанова в области гуманитарных наук; есть серебряная монета академик А. И. Крушанов руководитель ИИАЭ ДВО РАН; раз в два года проходит научная конференция - Крушановские чтения. В 1993 г. на здании созданного им ИИАЭ ДВО РАН была установлена мемориальная доска.

У истоков Института стояли ученые, оставившие заметный след в отечественной исторической науке. Среди них археологи д. и. н. Э. В. Шавкунов, положивший начало систематическим исследованиям в области средневековой археологии Дальнего Востока, д. и. н. Ж. В. Андреева - исследователь памятников первобытной археологии и железного века Приморья, к. и. н. В. Д. Леньков - специалист по древней металлургии чжурчжэней; этнографы д. и. н. Ю. А. Сем основатель дальневосточной этнографической школы, д. и. н. Н. В. Кочешков - крупнейший специалист по истории и культуре коренных народов Дальнего Востока и Центральной Азии; востоковеды д. и. н. В. Ф. Соловьёв - основатель дальневосточной школы по истории и культуре Китая, д. и. н. В. Г. Щебеньков - организатор советского японоведения на Дальнем Востоке; историки д. и. н. А. П. Деревянко исследователь истории Дальнего Востока в советский период, д. и. н. Л. И. Галлямова - специалист по истории рабочего класса Дальнего Востока в имперский период, д. и. н. А. Т. Мандрик, главной темой научного творчества которого стала история рыбной промышленности, д. и. Н. И. Г. Стрюченко, занимавшийся изучением истории культуры народов Дальнего Востока; д. и. н. Ю. В. Аргудяева, изучавшая материальную и духовную культуру русских дальневосточников; исследователи языка и культуры коренных малочисленных народов Дальнего Востока кандидаты исторических наук Л. И. Сем, Н. Б. Киле, Г. А. Отаина, Н. К. Старков, Е. А. Гаер. Большой вклад в становление социальной и демографической истории XX в. Дальнего Востока России внесла к. и. н. В. Е. Борчанинова.

К 1985 г. сотрудниками Института было опубликовано 2900 научных публикаций, из них 189 коллективных трудов (табл. 1) и 61 монография (табл. 2).

С 1991 по 2017 гг. ИИАЭ ДВО РАН возглавлял акад. РАН Виктор Лаврентьевич Ларин. Первые годы его руководства совпали со сложным периодом радикальных реформ в стране, повлёкших за собой коренные изменения общественно-политического и социально-экономического развития.

В начале 1991 г. научные сотрудники ИИАЭ АН СССР включились в обсуждение вопроса о «кризисе» современной исторической науки и путях его преодоления. Данной проблематике была посвящена научно-практическая конференция ИИАЭ ДВО РАН и ДВГУ «Социализм: история, современность и будущее» (Владивосток, 18 апреля 1991 г.). Часть историков и философов ИИАЭ и ДВГУ видела причины кризисных явлений исторической науки в отходе некоторых учёных от марксистско-ленинской диалектики, в приверженности их сталинскому догматизму [см.: $1,2,12,26]$; другие учёные основными причинами кризисных явлений советской исторической науки называли её замкнутость на единственно «правильной» марксистско-ленинской методологии, основанной на материалистической диалектике. По их мнению, методология исторического знания не должна ограничиваться только марксизмом [8], который фактически превратился в государственную идеологию и даже мировоззрение, присво- 


\begin{tabular}{|c|c|c|c|c|c|c|c|}
\hline $\begin{array}{c}\text { Жанры } \\
\text { и тематические направления }\end{array}$ & $\begin{array}{c}1971- \\
1985\end{array}$ & $\begin{array}{c}1986- \\
1995\end{array}$ & $\begin{array}{c}1996- \\
2000\end{array}$ & $\begin{array}{c}2001- \\
2005\end{array}$ & $\begin{array}{c}2005- \\
2010\end{array}$ & $\begin{array}{c}2011- \\
2015\end{array}$ & Итого \\
\hline Коллективные работы & 189 & 10 & & & & & 199 \\
\hline Философия. Социология & 49 & 60 & 8 & & & 32 & 149 \\
\hline История КПСС & 34 & & & & & & 34 \\
\hline Идеологическая работа & 226 & & & & & & 226 \\
\hline Отечественная история & 739 & 796 & 486 & 504 & 599 & 831 & 3955 \\
\hline Российская эмиграция в странах АТР & & & 97 & 31 & 26 & & 154 \\
\hline Историография и источниковедение & & & 39 & 53 & 100 & 100 & 292 \\
\hline История международных отношений & 202 & 345 & 217 & 150 & 236 & 574 & 1.724 \\
\hline История зарубежных стран & 574 & 394 & 131 & 180 & 171 & 167 & 1.617 \\
\hline Археология & 316 & 516 & 406 & 593 & 610 & 620 & 3061 \\
\hline Этнография. Филология & 445 & 339 & 329 & 338 & 452 & 421 & 2324 \\
\hline Учебные и справочные издания & & 19 & 52 & 41 & 37 & 42 & 191 \\
\hline Научно-популярные публикации & 126 & 106 & & & & & 232 \\
\hline ИТОГО: & 2900 & 2585 & 1765 & 1890 & 2231 & 2787 & 14158 \\
\hline
\end{tabular}

Табл. 1. Публикации сотрудников ИИАЭ ДВО РАН (1971-2015 гг.). Источник: подсчитано автором на основе библиографических указателей, издаваемых ИИАЭ $[27,28,29,30,31$, 32]. ив монопольное право определять, в каких рамках может и должна развиваться та или иная область гуманитарного знания. В освещении исторических событий необходим научный плюрализм.

Развитие политических процессов в 1990-1991 гг., приведшие к ликвидации КПСС, крушению советской системы, распаду СССР и т. д. оказали непосредственное влияние на историков России, привели к окончательному кризису марксистско-ленинской методологии, выступавшей основой советской исторической науки. Историческая наука перестала выполнять пропагандистско-идеологические функции в обществе.

Степень этого влияния по-разному оценивается различными исследователями. Ряд из них достаточно негативно оценивает то, что происходило в отечественной исторической науке в первой половине 1990-х годов. П. К. Гречко характеризует ситуацию, сложившуюся в исторической науке в это время, как «исторический беспредел», имеющий «ярко выраженный демократический уклон» [10, с. 84].

Ю. А. Поляков отмечал, что историческая наука в первой половине 1990-х годов «выглядела лишенной прежних и не создавшей новых концепций, с углубляющейся поляризацией, с амбициями новых лидеров и номенклатурно-должностными бастионами старых деканов, с недоразвитым догматизмом и вышедшей на авансцену конъюнктурной некомпетентностью» [24, с. 205]. На фоне этого господствовало критическое отношение к исторической науке в массовом сознании.

В наиболее сложной ситуации оказались историки российских регионов и региональные институты Академии наук с их филиалами, возникла определенная напряжённость во взаимоотношениях Москвы и российской «исторической периферии». 


\begin{tabular}{|l|c|c|c|c|c|c|c|}
\hline \multicolumn{1}{|c|}{ Тематические направления } & $\begin{array}{c}\mathbf{1 9 7 1 -} \\
\mathbf{1 9 8 5}\end{array}$ & $\begin{array}{c}\mathbf{1 9 8 6 -} \\
\mathbf{1 9 9 5}\end{array}$ & $\begin{array}{c}\mathbf{1 9 9 6 -} \\
\mathbf{2 0 0 0}\end{array}$ & $\begin{array}{c}\mathbf{2 0 0 1 -} \\
\mathbf{2 0 0 5}\end{array}$ & $\begin{array}{c}\mathbf{2 0 0 5 -} \\
\mathbf{2 0 1 0}\end{array}$ & $\begin{array}{c}\mathbf{2 0 1 1 -} \\
\mathbf{2 0 1 5}\end{array}$ & Итого \\
\hline Философия. Социология & 1 & 4 & & & & 3 & 8 \\
\hline Отечественная история & 38 & 31 & 16 & 31 & 35 & 20 & 171 \\
\hline Российская эмиграция в странах АТР & & & 3 & 2 & & & 5 \\
\hline Историография и источниковедение & 2 & 5 & & 4 & 4 & 1 & 16 \\
\hline История международных отношений & & 10 & 14 & 3 & 6 & 14 & 47 \\
\hline История зарубежных стран & 8 & 11 & 9 & 7 & 11 & 1 & 47 \\
\hline Археология & 4 & 12 & 11 & 20 & 35 & 28 & 110 \\
\hline Этнография. Филология & 8 & 22 & 18 & 14 & 20 & 15 & 97 \\
\hline ИТОГО: & 61 & 95 & 71 & 81 & 111 & 82 & 501 \\
\hline
\end{tabular}

На положение исторической науки на Дальнем Востоке в целом и её организацию в ИИАЭ в первой половине 1990-х годов значительное влияние оказывали последствия «перестроечных» лет, которые были на Дальнем Востоке более негативны, чем в центральных регионах страны: начался отток интеллектуальной элиты в европейскую часть России и в страны АТР; обострилась проблема демаркации границы; не был решен вопрос разграничения полномочий федерального центра и местных администраций; ярко проявил себя кризис военно-промышленного и энергетического комплексов, усугубленных в Приморье многолетним конфликтом краевой и городской администраций.

Значительные изменения в «перестроечные» годы получила региональная политика федеральной власти. Стали появляться и активно обсуждаться различные «научно обоснованные» проекты освоения российского Дальнего Востока вахтовым методом. Федеральные власти периодически обсуждали вопрос о необходимости снизить ставку дальневосточного коэффициента и лишения дальневосточников других льгот, обвиняли жителей региона в наличии сепаратистских настроений.

В такой ситуации перед руководством ИИАЭ ДВО РАН стояли довольно сложные задачи: сохранить кадры профессионалов-историков; выработать новые методологические подходы и принципы анализа исторических событий и «белых пятен» истории Дальнего Востока; определить перспективы на будущее.

В 1991 г. ушёл из жизни основатель и многолетний директор ИИАЭ д. и. н., акад. АН СССР А. И. Крушанов, и решать эти вопросы предстояло новому директору - д. и. н., проф. В. Л. Ларину.

Первая проблема, вставшая перед руководством Института, - материальная. В результате «шоковой терапии» произошло массовое обнищание российского населения, сопровождавшееся многомесячными задержками заработной платы, обесцениванием вкладов и пр. Практически прекратилось финансирование научных учреждений, дальневосточные историки потеряли возможность работы в федеральных и региональных архивах, нормальной организации археологических и этнографических экспедиций и пр. Всё это поставило
Табл. 2. Монографии сотрудников и соискателей ИИАЭ ДВО РАН (1971-2015 гг.). Источник: подсчитано автором на основе библиографических указателей, издаваемых ИИАЭ $[27,28,29,30,31$, 32]. 
региональные учреждения ДВО РАН, в том числе и ИИАЭ, на грань выживания.

Выживали как могли. Руководство Института истории, археологии и этнографии народов Дальнего Востока, чтобы иметь хоть какие-то материальные средства, вынуждено было сдавать в аренду помещения в знании ИИАЭ коммерческим и прочим организациям. Значительная часть научных сотрудников искала любую дополнительную работу; эти «подработки» часто не имели никакого отношения к истории: мыли полы, дежурили на вахте в различных учреждениях, занимались торговлей и пр. Понятно, что научный работник, большую часть своего времени тративший на поиск средств к существованию, не мог плодотворно заниматься научными исследованиями, что сказалось на количестве и качестве научных публикаций.

Вторая проблема - кадровая. В результате сокращения финансирования часть научных сотрудников ИИАЭ поменяла свою профессиональную деятельность. Кто-то ушёл в бизнес, кто-то переехал в центральные регионы страны. Определенная часть высококвалифицированных сотрудников в первой половине 1990-х гг. полностью перешли на преподавательскую работу: в 1992 г. вернулась на кафедру страноведения ДВГУ, с 1993 г. заведовала этой кафедрой, д. и. н., проф. Е. В. Верисоцская; в 1994 г. возглавил новую кафедру ДВГУ - кафедру археологии, этнографии и истории - д. и. н., проф. Э. В. Шавкунов.

Ушли работать в ДВГУ: к. и. н. В. В. Корсков (1992); к. и. н. 3. Ф. Моргун (1993); к. и. н. Е. Ю. Бондаренко; к. и. н. Н. Г. Егоров (1993); к. и. н. Т. А. Жарикова (1991); к. и. н. Г. Ф. Захарова (1995); к. и. н. Л. И. Клим. И. И. Баланева перешла на работу преподавателем японского языка в Дальневосточный политехнический институт (1992); к. и. н. Ю. М. Васильев переехал в Хабаровск и стал научным сотрудником Хабаровского краевого научного музея им. Гродекова; к. и. н. Г. В. Ожерельева вместе с мужем уехала работать в Японию (1990); ушла из Института и к. и. н. М. А. Патрушева (1992) и др.

Стабилизация положения с организацией научных исследований и финансированием научных учреждений ДВО РАН во второй половине 1990-х гг. опять делает работу ИИАЭ ДВО РАН привлекательной для молодых исследователей: во второй половине 1990-х гг. в ИИАЭ ДВО РАН пришли работать будущие кандидаты исторических наук: А. Г. Артамонов (1995); Г. Б. Дудченко (1998); Ю. Н. Ковалевская (Поповичева) (1996); С. Г. Коваленко (1996); В. А. Королёва (1996); Л. А. Крушанова (1997); Е. В. Сидоренко (1995); Л. А. Слабнина (1990) и др.

Третья проблема - выработка новых методологических подходов и принципов анализа исторических событий и «белых пятен» истории Дальнего Востока.

Необходимость выработки новых методологических подходов и принципов в освящение региональной истории побудило научных сотрудников Института принять участие в обсуждении ряда основополагающих категорий исторической науки, таких как «формация», «цивилизация», «исторический прогресс», «исторический регресс» и пр., которые активно обсуждались на страницах исторических изданий [см.: 11, 17, 19].

Историками ИИАЭ ДВО РАН была предпринята попытка создания новой концепции понимания и изучения истории Дальнего 
Востока. В журнале «Россия и АТР» (1995, № 2) были опубликованы статьи Н. В. Кочешкова [20], А. С. Ващук [5], Н. П. Рябченко [25], Б. И. Мухачёва [22], А. Т. Мандрика [21], посвящённые данной концепции.

В данных статьях к разряду методологически новых подходов следует отнести новые импульсы взгляда на историю российского Дальнего Востока, помогающие понять всю её многомерность и противоречивость. Дальнейшее развитие новая концепция получила в работах А. С. Ващук [см.: 3, 4, 7]. В рамках новой концепции иначе стали рассматриваться проблемы ДВР [см.: 21; 23], различные альтернативы становления и развития дальневосточного социализма.

Не менее значимой для историков ИИАЭ в 1990-е годы стала проблема отношения к активно обсуждаемых в российской исторической науке подходам: цивилизационному и формационному. Развёрнутая критика марксизма привела к тому, что в отечественной исторической науке возобладала точка зрения, что основным в объяснении событий отечественной истории доложен стать цивилизационный подход. Рассматривая два основных подхода в освящении отечественной истории, А. С. Ващук обратила внимание на то, что невозможно вписать историю России в рамки одной цивилизации, что историки по-разному понимают, к какому типу цивилизации необходимо относить Россию: европейской или евразийской. Поэтому она настаивает, что изучать историю России можно и нужно используя два подхода: и цивилизационный, и формационный [см.: 4, 5]. Помимо этих подходов необходимо использовать концепцию модернизации и региональный подход, которые позволяют рассматривать события истории российского Дальнего Востока как часть тех медернизационных процессов, которые проходили в стране в целом, но имели свои региональные особенности.

Наиболее сложной задачей, стоявшей перед ИИАЭ в 1990-е годы, была задача определения основных направлений исторических исследований, в первую очередь это касалось отечественной истории, ибо исследования по всемирной истории, археологии и этнографии в меньшей степени зависели от методологический установок, выработанных в марксистско-ленинской философии.

После распада СССР по инициативе директора В. Л. Ларина в ИИАЭ ДВО РАН произошли структурные изменения: был ликвидирован Отдел идеологической работы; созданы ряд новых Центров, в том числе Центр по изучению социально-политических исследований (1994); Центр изучения российской эмиграции (1995) и ряд других.

Анализ публикаций этого периода показывает, что интерес к социально-экономической истории Дальнего Востока упал; на первое место вышло исследование социально-политической проблематики. Это можно объяснить рядом причин. Во-первых, слабой её разработкой в советской дальневосточной историографии; во-вторых, сменой методологических парадигм. Руководитель Центра социально-политических исследований д. и. н., проф. А. С. Ващук не только сформулировала основные методологические подходы к изучению социально-политической истории Дальневосточного региона, см.: [7, 9], но и создала творческий коллектив, который заметно проявил себя уже в конце 1990-х гг. (Е. Н. Чернолуцкая, Ю. Н. Ковалевская (Поповичева), Л. А. Крушанова, Г. Б. Дудченко и др.). 
В 1990-е гг. сотрудники ИИАЭ обратились к изучению тех социальных слоёв, которые не пользовались ранее вниманием историков: предприниматели, дворянство, чиновничество, купечество и особенно казачество (О. И. Сергеев, С. И. Лазарева, Ю. Н. Поповичева и др.).

Одной из новых тем, активно разрабатываемой с 1990-х гг., становится история восточной ветви российской эмиграции. Если в 19901991 гг. не было ни одной публикации по истории российской эмиграции, то с 1993 г. данная тематика становится востребованной (табл. 1). О. И. Сергеев, С. И. Лазарева, С. Б. Белоглазова, Н. Л. Горкавенко, Н. П. Гридина, В. Ф. Печерица, Н. А. Василенко и др. сотрудники ИИАЭ рассматривали в своих работах те или иные стороны жизни восточной ветви российской эмиграции; повседневную жизнь русских эмигрантов в Китае, Австралии, США и пр. Создание Центра изучения российской эмиграции говорит о том, что история эмиграции, рассеяния россиян перестает быть запретной, что история зарубежной России начинает восприниматься как часть отечественной истории.

Ещё со времён перестройки в ИИАЭ началось изучение истории православия на Дальнем Востоке. Это и роль православия в культуре Дальнего Востока (А. Р. Артемьев), и история православия в Русской Америке (С. Б. Белоглазова), и изучение жизни и деятельности православных иерархов (Г. В. Прозорова). Однако эти работы носили фрагментарный характер и не давали полного представления о роли Русской православной церкви в хозяйственном и культурном освоении региона. В настоящее время, помимо истории РПЦ, сотрудники ИИАЭ (Дударёнок С. М., Федирко О. П.) активно занимаются историей религиозных общин Дальнего Востока. За последние пару лет вышло уже три монографии из серии «Религиозная жизнь Дальнего Востока России»,см. [13; 14; 15].

Одной из приоритетных тем научных исследований с 1990-х гг. становится проблема миграций, как принудительных, так и добровольных, а также формирование трудовых ресурсов и роль в этом процессе органов власти. Активно занимались данной проблематикой А. С. Ващук, Е. Н. Чернолуцкая, Г. А. Ткачёва, Г. Б. Дудченко и др.

Большая работа в 1990-е гг. была проделана по рассекречиванию архивных документов. Наибольший интерес для сотрудников ИИАЭ представляли архивные документы периода сталинских репрессий. Репрессии против различных категорий населения становятся ещё одним новым направлением исторических исследований. Репрессии среди вузовских преподавателей исследовал В. Г. Макаренко, в среде крестьянства - Л. И. Проскурина; в рыбной промышленности - А. Т. Мандрик; в целом историю Дальневосточного ГУЛАГа А. П. Деревянко.

Ещё одним новым направлением исторических исследований в ИИАЭ становится так называемая история повседневности, позволяющая пролить дополнительный свет на глубинные, личностнообщественные процессы, протекающие в том или ином обществе. «Героями» исследования становятся не народы, классы, социальные группы, а «живые» «простые люди» с их обыденными взаимоотношениями, надеждами, разочарованиями, планами, причём на разных ступенях общественной лестницы. С позиций истории повседневности стали изучаться история и культура дальневосточных 
городов (Т. 3. Позняк); жизнь и деятельность российских женщин в Маньчжурии (С. И. Лазарева) и др.

Огромной популярностью среди сотрудников ИИАЭ в 1990-е годы пользовался такой жанр исторических публикаций, как историческая биография, см. [18]. Были написаны исторические биографии Н. П. Матвеева (Л. И. Галлямова, Л. Я. Иващеко); А. И. Крушанова (А. П. Деревянко, Э. В. Ермакова, А. Т. Мандрик, М. А. Патрушева); К. А. Харнского (Е. Ю. Бондренко); В. М. Савича (Е. В. Васильева); В. К. Арсеньева (Л. Я. Иващенко); С. Н. Стебницкого (Л. Я. Иващеко); Л. Н. Иваньева (Н. А. Клюев); В. И. Иохельсона (Н. В. Кочешков); А. М. Кранощекова (Б. И. Мухачёв); С. П. Крашеннинокова (В. Н. Чернавская); Б. О. Пилсудского (Т. С. Шульгина) и многих других известных дальневосточников.

Труднейшая задача - сохранить традиции и основной костяк Института в сложный период радикальных реформ, привлечь к работе молодых специалистов, развернуть исследования по новым перспективным направлениям - была В. Л. Лариным в основном успешно решена.

Под его руководством учёные Института стали вести исследования по 5 укрупнённым темам, в рамках которых разрабатывалось 14 актуальных научных проблем, в том числе «Человек на восточном побережье Евразии в условиях традиционного общества»; «Россия и народы Дальнего Востока: опыт цивилизационно-культурного взаимодействия»; «Этнокультурные и демографические процессы на Дальнем Востоке России и в странах АТР»; «Исторический опыт освоения русскими тихоокеанских берегов России»; «Трансформация общества и власти на российском Дальнем Востоке во второй половине XX - начале XXI в.»; «Россия в системе международных отношений и обеспечения безопасности в АТР» и др.

С октября 1992 г. Институт стал издавать научный журнал «Россия и АТР», продолжал активно работать редакционно-издательский отдел, аспирантура, докторский совет по четырём специальностям (отечественной и всеобщей истории, археологии и этнографии), был создан Музей археологии и этнографии, в фондах которого более 100 тыс. уникальных экспонатов.

Виктор Лаврентьевич придавал огромное значение развитию научных международных отношений, были установлены связи с 17 университетами и научными организациями Японии, КНР, Республики Корея, США, Франции, Австралии. Среди совместных проектов международные конференции, археологические и этнографические экспедиции, стажировки специалистов, совместные публикации, обмен изданиями.

За период с 1986 по 2015 гг. сотрудниками Института было опубликовано 14158 научных работ (табл. 1). Наибольшее количество работ было посвящено проблемам отечественной истории и истории Дальнего Востока России (3 216 публ.). На втором месте находятся археологи, которые продолжали заниматься проблемами первобытной и средневековой истории Дальнего Востока; изучением истории и культуры государства Бохай и золотой империи Цзинь (2 745 публ.). На третьем месте - этнографы и филологи, которые продолжили научную традицию предыдущего периода и активно занимались изучением быта, культуры и обычаев коренных малочисленных народов 


\begin{tabular}{|l|c|c|c|c|c|c|c|c|}
\hline \multicolumn{1}{|c|}{ Виды диссертаций } & $\begin{array}{c}\mathbf{1 9 7 1 -} \\
\mathbf{1 9 8 5}\end{array}$ & $\begin{array}{c}\mathbf{1 9 8 6 -} \\
\mathbf{1 9 9 5}\end{array}$ & $\begin{array}{c}\mathbf{1 9 9 6 -} \\
\mathbf{2 0 0 0}\end{array}$ & $\begin{array}{c}\mathbf{2 0 0 1 -} \\
\mathbf{2 0 0 5}\end{array}$ & $\begin{array}{c}\mathbf{2 0 0 5 -} \\
\mathbf{2 0 1 0}\end{array}$ & $\begin{array}{c}\mathbf{2 0 1 1 -} \\
\mathbf{2 0 1 5}\end{array}$ & $\begin{array}{c}\mathbf{2 0 1 6 -} \\
\mathbf{2 0 2 0}\end{array}$ & Итого \\
\hline Докторские & 8 & 10 & 12 & 7 & 4 & 2 & & 43 \\
\hline Кандидатские & 122 & 56 & 30 & 52 & 46 & 6 & 2 & 314 \\
\hline ИТОГО: & 130 & 66 & 42 & 59 & 50 & 8 & 2 & 357 \\
\hline
\end{tabular}

Табл. 3. Докторские и кандидатские диссертации, защищенные сотрудниками и в диссертационных советах ИИАЭ ДВО РАН. Источник: Подсчитано автором на основе библиографических указателей, издаваемых ИИАЭ $[27,28,29,30,31$, 32] и авторефератов диссертаций.
Дальнего Востока России (1 879 публ.). Стабильным, был интерес к проблемам внешней политики и международным отношениям (1 522 публ.), и всеобщей истории (1 043 публ.). Интерес к проблемам безопасности и международным отношениям возрос в 2011-2015 гг. более чем в два раза (575 публ.) по сравнению с 2005-2010 гг. (236 публ.).

Наиболее значимыми публикациями для историков всегда были индивидуальные и коллективные монографии, которые позволяют не только обозначить научную проблему, но и решить её.

В 1986-2015 гг. сотрудниками ИИАЭ ДВО РАН было опубликовано 440 монографий: 133 монографии по отечественной истории и истории Дальнего Востока; 116 - археологии; 89 - по этнологии и филологии 47 - внешней политике и международным отношениям; 39 - всеобщей истории; 14 - историографии и источниковедению; 5 истории российской эмиграции и 8 по философии.

Особое значение в исторических исследованиях всегда занимали и занимают диссертационные исследования. Диссертация как научноисследовательская работа является определённой вехой в деятельности любого историка. За период своего существования сотрудниками ИИАЭ и в диссертационных советах ИИАЭ ДВО РАН было защищено 43 докторские и 314 кандидатских диссертаций (табл. 3,4$)$.

Таблица 3. Докторские и кандидатские диссертации, защищенные сотрудниками и в диссертационных советах ИИАЭ ДВО РАН. Источник: Подсчитано автором на основе библиографических указателей, издаваемых ИИАЭ [27, 28, 29, 30, 31, 32] и авторефератов диссертаций.

Одним из показателей научной активности историков были и остаются научные конференции. Участие в конференции даёт не только возможность пообщаться с коллегами и поучаствовать в дискуссии, но и поделиться своими научными достижениями и результатами. Без подобного общения историк становится «историком сам для себя», он не может получить квалифицированную оценку результатов своего труда.

За период с 1971 по 2020 гг. Институт выступил организатором и соорганизатором 417 научных мероприятий, 141 из них международного уровня, табл. 5 .

С 2018 г. ИИАЭ ДВО РАН возглавляет чл.-корр. РАН Николай Николаевич Крадин, который стремится не только продолжить и развить традиции, заложенные его предшественниками, но и вывести Институт на новые высоты. Научные достижения Института - это результат совместных усилий всех его сотрудников от директора до младшего научного сотрудника и лаборанта.

Сегодня в структурных подразделениях Института работают 92 научных сотрудника, 58,7\% (54) из них - доктора и кандидаты наук. 


\begin{tabular}{|l|c|c|}
\hline \multirow{2}{*}{ Тематические направления } & \multicolumn{2}{c|}{ Количество } \\
& диссертационых работ \\
\cline { 2 - 3 } & Всего & \% \\
\hline $\begin{array}{l}\text { Отечественная история. } \\
\text { Социальная и политическая история Дальнего Востока России }\end{array}$ & 129 & $36,13 \%$ \\
\hline $\begin{array}{l}\text { История промышленности и сельского хозяйства Дальнего } \\
\text { Востока России; история рабочего класса и крестьянства }\end{array}$ & 39 & $10,92 \%$ \\
\hline Археология & 40 & $11,20 \%$ \\
\hline Этнография & 34 & $9,52 \%$ \\
\hline Культура Дальнего Востока России и сопредельных стран & 42 & $11,76 \%$ \\
\hline История международных отношений & 36 & $10,08 \%$ \\
\hline Всеобщая история & 24 & $6,72 \%$ \\
\hline Философия & 5 & $1,40 \%$ \\
\hline Филология, педагогика & 8 & $2,24 \%$ \\
\hline ИТОГО: & 357 & $100 \%$ \\
\hline
\end{tabular}

В последние пять лет учёные Института вели исследования по 6 укрупнённым темам: «Традиционные культуры российского Дальнего Востока в историко-культурном ландшафте Азиатско-Тихоокеанского региона»; «Историко-культурные ландшафты островной и прибрежной зон Северной Пасифики»; «Археология и история юга Дальнего Востока России и смежных зон Азии в древности и средневековье»; «Трансформация общества и власти на российском Дальнем Востоке во второй половине XX - начале XXI в.»; «Тихоокеанская Россия: исторические модели освоения, место региона в общероссийском и восточноазиатском цивилизационном пространстве»; «Россия в планах и политике стран Северной Пасифики в контексте современных проектов евразийской интеграции и новой геополитической ситуации в зоне Тихоокеанской Азии».

В рамках этих тем разрабатывались ряд актуальных научных проблем и проектов, в том числе такие проекты как «Экономическая, социокультурная, политическая и гуманитарная безопасность Тихоокеанской России в национальном и международном контекстах»; «Приграничные регионы Дальнего Востока в условиях быстрых социальных изменений 1987 - 2017 гг.: опыт развития и обеспечения безопасности»; «Малая Восточная Азия на Дальнем Востоке России: исторический опыт и современные проблемы этнокультурного сосуществования россиян и мигрантов из Восточной Азии»; «Влияние региональной политики на международную интеграцию периферийных территорий (на примере стран Северо-Восточной Азии)»; «Этномиграционные процессы в Приморье в XX - начале XXI в.»; «Социально-политическая безопасность Дальнего Востока России в XX-начале XXI в.»; «Политико-административные проблемы управления ускоренным развитием: история особых экономических зон на Дальнем Востоке России»; «Городища и крепости Дальнего Востока (Приморье, Приамурье)» и др. В результате активизировалась публикационная активность сотрудников ИИАЭ.
Табл. 4. Тематика диссертационных работ, защищенных сотрудниками и в диссертационных советах ИИАЭ ДВО РАН. Источник: подсчитано автором на основе библиографических указателей, издаваемых ИИАЭ [cм.: 27, 28, 29, 30, $31,32]$ и авторефератов диссертаций 


\begin{tabular}{|l|c|c|c|c|c|c|c|c|}
\hline $\begin{array}{c}\text { Уровни и типы } \\
\text { научных мероприятий }\end{array}$ & $\begin{array}{c}\mathbf{1 9 7 1 -} \\
\mathbf{1 9 8 5}\end{array}$ & $\begin{array}{c}\mathbf{1 9 8 6 -} \\
\mathbf{1 9 9 5}\end{array}$ & $\begin{array}{c}\mathbf{1 9 9 6 -} \\
\mathbf{2 0 0 0}\end{array}$ & $\begin{array}{c}\mathbf{2 0 0 1 -} \\
\mathbf{2 0 0 5}\end{array}$ & $\begin{array}{c}\mathbf{2 0 0 5 -} \\
\mathbf{2 0 1 0}\end{array}$ & $\begin{array}{c}\mathbf{2 0 1 1 -} \\
\mathbf{2 0 1 5}\end{array}$ & $\begin{array}{c}\mathbf{2 0 1 6 -} \\
\mathbf{2 0 2 0}\end{array}$ & Итого \\
\hline Международные & 1 & 17 & 16 & 27 & 25 & 19 & 36 & 141 \\
\hline $\begin{array}{l}\text { Всероссийские } \\
\text { (всесоюзные) }\end{array}$ & 1 & & 1 & 1 & 8 & 1 & 9 & 21 \\
\hline Региональные & 23 & 23 & 12 & 11 & 8 & 3 & 9 & 89 \\
\hline Институтские & 31 & 20 & 7 & 4 & 6 & 5 & 27 & 100 \\
\hline Круглый стол & & & 6 & 1 & 15 & 18 & 26 & 66 \\
\hline ИТОГО: & 56 & 60 & 42 & 44 & 62 & 46 & 107 & 417 \\
\hline
\end{tabular}

Табл. 5. Конференции, проведенные ИИАЭ ДВО РАН (1971-2020 гг.). Источник: подсчитано автором на основе библиографических указателей, издаваемых ИИАЭ [CM.: 27, 28, 29, 30, $31,32]$ и годовых научных отчетов ИИАЭ ДВО РАН
В конце 2020 г. Учёным советом ИИАЭ ДВО РАН были определены новые укрупненные темы исследований для различных структурных подразделений Института. Как и в предыдущий период, данные темы позволяют выделить наиболее значимые и актуальные научные проблемы, на решение которых будет направлена деятельность научных сотрудников. За последние пять лет (2016-2020) научными сотрудниками ИИАЭ было опубликовано 2261 научный публикаций, из них 33 монографии и 206 публикаций, изданных за рубежом.

Институт осуществляет многоплановое сотрудничество (проведение совместных научных исследований и конференций, подготовка кадров высшей квалификации, стажировки научных сотрудников и преподавателей и др.) с вузами Приморского края и Дальневосточного региона. Помимо руководства научно-исследовательской работой студентов и магистрантов сотрудники Института проводили и проводят археологические практики для студентов ДВФУ гуманитарных дисциплин, являлись председателями ГАК и ГЭК. Более трети научных сотрудников Института преподают в вузах: ДВФУ, МГУ им. Невельского, ВГУЭС, ДВГАИ, СахГу, где читают учебные дисциплины и оригинальные курсы по гуманитарным специальностям.

Кроме ВУЗов ИИАЭ ДВО РАН активно сотрудничает со школами (школа-интернат им. Дубинина), гимназиями (гимназия № 1), учреждениями дополнительного образования. Сотрудники Института участвуют в качестве организаторов, членов жюри, модераторов секций на конкурсах, олимпиадах, школьных конференциях.

Активно сотрудничает ИИАЭ с органами государственной власти, это сотрудничество осуществляется путём проведения семинаров, научных экспертиз, консультаций, ситуационных анализов, систематической подготовки справок, докладов, информационно-аналитических бюллетеней об изменениях международной обстановки в АТР, политической, экономической, этнической, культурной ситуации на российском Дальнем Востоке, на смежных территориях СевероВосточной Азии и др.

ИИАЭ имеет четыре периодических издания. С октября 1992 г. издаётся научный журнал «Россия и АТР» (главный редактор - акад. РАН, д. и. н., проф. В. Л. Ларин). На страницах журнала освещаются проблемы истории, археологии и этнографии, культуры, политики и международных отношений, связанные с Дальним Востоком России и сопредельными странами Азиатско-Тихоокеанского региона. Миссия 
журнала - объединять исследователей вокруг наиболее важных проблем прошлого и настоящего этой динамично развивающейся части мира.

В 2019 г. было возобновлено издание информационно-аналитического бюллетеня «У карты Тихого океана» (главный редактор - акад. РАН, д. и. н., проф. В. Л. Ларин). Бюллетень издавался с 1974 по 1991 г. Цель издания - научно-информационное обеспечение мероприятий правительства РФ и региональных властей Дальнего Востока по интеграции России в АТР.

«Труды Института истории, археологии и этнографии ДВО РАН» (главный редактор - чл.-корр. РАН, д. и. н., директор ИИАЭ ДВО РАН Н. Н. Крадин) основаны в 1959 г. под первоначальным названием «Труды Отдела истории и археологии Дальневосточного филиала Сибирского отделения Академии наук СССР». С 2018 г. издание выходит 4 раза в год как регулярное научное рецензируемое издание.

Научный журнал «Мультидисциплинарные исследования в археологии» (главный редактор - чл.-корр. РАН, д. и. н., директор ИИАЭ ДВО РАН Н. Н. Крадин) создан на основе продолжающегося издания с одноимённым названием, выпускавшегося в 2014-2017 гг. На страницах журнала освещаются проблемы мультидисциплинарных исследований в археологии не только Дальнего Востока и Сибири, но и более широких территорий, включая Северную и Северо-Восточную Азию. Целью создания журнала является консолидация усилий исследователей в изучении истории человечества с использованием методов и достижений разных областей знаний.

Институт развивает международные связи с 17 университетами и научными организациями Японии, Республики Корея, КНР, США, Франции, Австралии, Тайваня, Сингапура и других стран. Среди совместных проектов - международные конференции, археологические и этнографические экспедиции, стажировки специалистов, совместные публикации, обмен изданиями и пр.

В истории становления и развития дальневосточной академической исторической науки воедино слились прошлое, настоящее и будущее.

Становления дальневосточной академической исторической науки началось в Отделе истории и археологии Дальневосточного филиала СО АН СССР, продолжилось в ИИАЭ ДВНЦ АН СССР и ИИАЭ ДВО АН СССР и продолжает развиваться в Институте истории, археологии и этнографии народов Дальнего Востока ДВО РАН.

Мы благодарны прошлому, в котором закладывались традиции дальневосточной академической исторической науки. Мы благодарны настоящему, которое дало могучий импульс развитию исторического знания и исторической науке. Мы входим в будущее с большим потенциалом в области научной и просветительской деятельности. 


\section{Литература}

1. Алексенцев В. М. Ленининзм в свете диалектики истории // Ленин. Социализм. Современность: Тез. докл. науч.-прак. конф. «Социализм: История, современность и будущее». Препринт. Владивосток, 1991. С. 6-8.

2. Арлычев А. Н. Ленинская концепция социалистического «базиса» и её практическая реализация // Ленин. Социализм. Современность: Тез. докл. науч.-прак. конф. «Социализм: История, современность и будущее». Препринт. Владивосток, 1991. С. 3-5.

3. Ващук А. С. Актуальные проблемы изучения социальной истории // Россия и ATP. 2006. № 2. С. 22-40.

4. Ващук А. С. Главные задачи историков: Направления и результаты исследований отечественной истории // Россия и ATP. 1996. № 2. С. 16-24.

5. Ващук А. С. Двумя методами: Изучать прошлое - цивилизационным и формационным: Концепции развития российского общества // Россия и АТР. 1995. № 2. C. 6-12.

6. Ващук А. С. История Дальнего Востока в советский период: концепции 6090-х годов // Вестник ДВО РАН. 1996. № 2. C. $12-23$.

7. Ващук А. С. Научные поиски: Аналитико-библиографический обзор // Россия и АТР. 2011. № 2. С. 74-95.

8. Ващук А. С. Социальная политика в СССР и её реализация на Дальнем Востоке СССР (1945 - сер. 80-х гг.) // Ленин. Социализм. Современность: Тез. докл. науч.-прак. конф. «Социализм: История, современность и будущее». Препринт. Владивосток, 1991. С. 20-21.

9. Ващук А. С. Социальная политика в СССР и её реализация на Дальнем Востоке (середина 40 - 80-х годов ХХ в.). Владивосток: Дальнаука, 1998. 212 с.

10. Гречко П. К. О сознании, истине и лжи в истории // Вестник Российского ун-та дружбы народов. Серия «История, философия». 1993. № 1.

11. Дезер М. Крайности истории и крайности историков // Крайности истории и крайности историков: Сб. ст. М.:

\section{РНИСИНП, 1997. 279 с.}

12. Деревянко А. П. Ленинские идеи комплексного освоения восточных районов и их реализация // Ленин. Социализм. Современность: Тез. докл. науч.-прак. конф. «Социализм: История, современность и будущее». Препринт. Владивосток, 1991. С. $12-15$.

13. Дударёнок С. М., Федирко О. П. и др. История евангельских христиан-баптистов Дальнего Востока России в XIX-XX вв. / Отв. ред. Дударёнок С. М., Федирко О. П., Чернявский М. С. [Религиозная жизнь Дальнего Востока России]. ИИАЭ ДВО РАН. СПб.: Реноме, 2021. 544 с.

14. Дударёнок С. М., Федирк О. П. и др. История христиан веры евангельской (пятидесятников) Дальнего Востока России (1920-е - конец 1980-х гг.): монография / Отв. редактор О. П. Федирко. [Религиозная жизнь Дальнего Востока России] М.: ООО «Терция», 2018. 464 с.

15. Дударёнок С. М., Федирко О. П. Церковь христиан адвентистов седьмого дня Дальнего Востока России (1910-1990-е гг.): монография / Отв. редактор С. М. Дударёнок [Религиозная жизнь Дальнего Востока России] ИИАЭ ДВО РАН. М.: ООО «Терция», 2019. $472 \mathrm{c}$.

16. Институту истории, археологии и этнографии народов Дальнего Востока 40 лет // Россия и АТР. 2011. № 2. С. 5.

17. Искендеров А. А. Историческая наука на пороге XXI века // Вопросы истории. 1996. № 4.

18. История Дальнего Востока в лицах. Забытые имена. Вып. 1: Ст. и очерки / Редкол.: И. Г. Стрюченко (отв. ред.) и др. Владивосток: Дальнаука, 1994. 182 с.

19. Ковальченко И. Д. Теоретико-методологические проблемы исторических исследований. Заметки и размышления о новых подходах // Новая и новейшая история. 1995. № 1.

20. Кочешков Н. В. Об итогах конкурса: К вопросу о создании новой концепции исторического процесса на Дальнем Востоке России 1917-1991 г. // Россия и АТР. 1995. № 2. С. 5-6.

21. Мандрик А. Т. На марксистских дог- 
мах...: Строительство «государственного социализма» на Дальнем Востоке России в 1920-1930-е годы ХХ столетия // Россия и ATP. 1995. № 2. C. 27-31.

22. Мухачёв Б. И. «Белые пятна» Красного октября // Россия и АТР. 1995. № 2. C. 21-26.

23. Мухачёв Б. И. Правда истории: Дальневосточная республика и борьба с интервенцией на Дальнем Востоке // Россия и АТР. 1992. № 1. С. 11-22.

24. Поляков Ю. А. Наше непредсказуемое прошлое: Полемические заметки. М.: АИРО-ХХ, 1995. 214 c.

25. Рябченко Н. П. Россия, Дальний Восток и «социализм» // Россия и АТР. 1995. № 2. С. 12-20.

26. Сухин Ю. И. Логико-методологический аспект ленинской концепции социализма // Ленин. Социализм. Современность: Тез. докл. науч.-прак. конф. «Социализм: История, современность и будущее». Препринт. Владивосток, 1991. C. 9-11.
27. Труды Института истории, археологии и этнографии народов Дальнего Востока ДВНЦ АН СССР. 1971-1985 гг. Владивосток: ДВНЦ АН СССР, 1986. 294 с.

28. Труды Института истории, археологии и этнографии народов Дальнего Востока ДВО РАН. 1986-1995 гг.: Библиогр. указ. Владивосток: Дальнаука, 1996. 204 с.

29. Труды Института истории, археологии и этнографии народов Дальнего Востока ДВО РАН. 1996-2000 гг.: Библиогр. указ. Владивосток: Дальнаука, 2001. 172 с.

30. Труды Института истории, археологии и этнографии народов Дальнего Востока ДВО РАН. 2000-2005 гг.: Библиогр. указ. Владивосток: Дальнаука, 2006. 212 с.

31. Труды Института истории, археологии и этнографии народов Дальнего Востока ДВО РАН. 2006-2010 гг.: Библиогр. указ. Владивосток: Дальнаука, 2011. 288 с.

32. Труды Института истории, археологии и этнографии народов Дальнего Востока ДВО РАН. 2011-2015 гг.: Библиогр. указ. Владивосток: Дальнаука, 2017. 336 с.

Svetlana M. DUDARENOK,

Ph. D. (in History), Leading Research Fellow, Department of Social and Political Research, Institute of History, Archeology and Ethnography of the Peoples of the Far East (Vladivostok, Russia).

E-mail: dudarenoksv@gmail.com

\title{
Institute of History, Archeology and Ethnography of the Peoples of the Far East of FEB RAS celebrates its 50th anniversary
}

\author{
DOI https://doi.org/10.24866/2542-1611/2021-2/6-21
}

On July 1, 2021, the Institute of History, Archeology and Ethnography of the Peoples of the Far East of the Far Eastern Branch of the Russian Academy of Sciences celebrated its fiftieth anniversary! Its creation in 1971 and its formation took place at a very remarkable time for the Russian Far East: there was a process of intensive exploitation of the natural resources of the region, new industrial enterprises and universities were created, Far Eastern cities were updated, and the population was growing. The ideological and military confrontation between the two "superpowers» grew, and relations between the USSR and the PRC sharply worsened. Under these conditions, the role of the humanitarian and ideological component of the social life of the region, which was to be formed by historical science, increased. The first and permanent head of the Institute for 20 years was Academician of the USSR Academy of Sciences Andrey Ivanovich Krushanov (1921-1991). From 1991 to 2017, the Institute was 
headed by the Academician of RAS Viktor Lavrentievich Larin. The first years of his leadership coincided with a difficult period of radical reforms in the country, which entailed fundamental changes in socio-political and socio-economic development. In such a situation, the administration of the Institute faced quite difficult tasks: to retain the staff of professional historians; to develop new methodological approaches and principles for analyzing historical events and "white spots» in the history of the Far East; to determine prospects for the future. Since 2018, the IIAE of the Far Eastern Branch of the Russian Academy of Sciences has been headed by Corresponding Member of the RAS Nikolai Nikolaevich Kradin, who seeks not only to continue and develop the traditions laid down by his predecessors, but also to bring the Institute to new heights. The scientific achievements of the Institute are the result of the joint efforts of all its employees from the director to a junior researcher and a laboratory assistant.

For citation: Dudarenok S. M. Institute of History, Archeology and Ethnography of the Peoples of the Far East of FEB RAS celebrates its 50th anniversary // Oriental Institute Journal. 2021. № 2. P. 6-21. DOI https://doi. org/10.24866/2542-1611/2021-2/6-21

\section{References}

1. Aleksentsev V. M. Lenininzm v svete dialektiki istorii // Lenin. Sotsializm. Sovremennost': Tez. dokl. nauch.-prak. konf. «Sotsializm: Istoriya, sovremennost' i budushhee». Preprint. Vladivostok, 1991. S. $6-8$.

2. Arlychev A. N. Leninskaya kontseptsiya sotsialisticheskogo «bazisa» i eyo prakticheskaya realizatsiya // Lenin. Sotsializm. Sovremennost': Tez. dokl. nauch.-prak. konf. «Sotsializm: Istoriya, sovremennost' i budushhee». Preprint. Vladivostok, 1991. S. 3-5.

3. Vashhuk A. S. Aktual'nye problemy izucheniya sotsial'noj istorii // Rossiya i ATR. 2006. № 2. S. 22-40.

4. Vashhuk A. S. Glavnye zadachi istorikov: Napravleniya i rezul'taty issledovanij otechestvennoj istorii // Rossiya i ATR. 1996. № 2. S. 16-24.

5. Vashhuk A. S. Dvumya metodami: Izuchat' proshloe - tsivilizatsionnym i formatsionnym: Kontseptsii razvitiya rossijskogo obshhestva // Rossiya i ATR. 1995. № 2. S. 6-12.

6. Vashhuk A. S. Istoriya Dal'nego Vostoka v sovetskij period: kontseptsii 6090-kh godov // Vestnik DVO RAN. 1996. № 2. S. 12-23.
7. Vashhuk A. S. Nauchnye poiski: Analitiko-bibliograficheskij obzor // Rossiya i ATR. 2011. № 2. S. 74-95.

8. Vashhuk A. S. Sotsial'naya politika v SSSR i eyo realizatsiya na Dal'nem Vostoke SSSR (1945 - ser. 80-kh gg.) // Lenin. Sotsializm. Sovremennost': Tez. dokl. nauch.-prak. konf. «Sotsializm: Istoriya, sovremennost' i budushhee». Preprint. Vladivostok, 1991. S. 20-21.

9. Vashhuk A. S. Sotsial'naya politika $v$ SSSR i eyo realizatsiya na Dal'nem Vostoke (seredina 40 - 80-kh godov XX v.). Vladivostok: Dal'nauka, 1998. $212 \mathrm{~s}$.

10. Grechko P. K. O soznanii, istine i lzhi v istorii // Vestnik Rossijskogo un-ta druzhby narodov. Seriya «Istoriya, filosofiya». 1993. № 1.

11. Dezer M. Krajnosti istorii i krajnosti istorikov // Krajnosti istorii i krajnosti istorikov: Sb. st. M.: RNISINP, 1997. 279 s.

12. Derevyanko A. P. Leninskie idei kompleksnogo osvoeniya vostochnykh rajonov i ikh realizatsiya // Lenin. Sotsializm. Sovremennost': Tez. dokl. nauch.-prak. konf. «Sotsializm: Istoriya, sovremennost' i budushhee». Preprint. Vladivostok, 1991. S. 12-15.

13. Dudaryonok S. M., Fedirko O. P. i dr. 
Istoriya evangel'skikh khristian-baptistov Dal'nego Vostoka Rossii v XIX-KHKH vv. / Otv. red. Dudaryonok S. M., Fedirko O. P., CHernyavskij M. S. [Religioznaya zhizn' Dal'nego Vostoka Rossii]. IIAEH DVO RAN. SPb.: Renome, 2021. $544 \mathrm{~s}$.

14. Dudaryonok S. M., Fedirk O. P. i dr. Istoriya khristian very evangel'skoj (pyatidesyatnikov) Dal'nego Vostoka Rossii (1920-e - konets 1980-kh gg.): monografiya / Otv. redaktor O. P. Fedirko. [Religioznaya zhizn' Dal'nego Vostoka Rossii] M.: OOO «Tertsiya», 2018. $464 \mathrm{~s}$.

15. Dudaryonok S. M., Fedirko O. P. TSerkov' khristian adventistov sed'mogo dnya Dal'nego Vostoka Rossii (1910-1990-e gg.): monografiya / Otv. redaktor S. M. Dudaryonok [Religioznaya zhizn' Dal'nego Vostoka Rossii] IIAEH DVO RAN. M.: OOO «Tertsiya», 2019. $472 \mathrm{~s}$.

16. Institutu istorii, arkheologii i ehtnografii narodov Dal'nego Vostoka - 40 let // Rossiya i ATR. 2011. № 2. S. 5.

17. Iskenderov A. A. Istoricheskaya nauka na poroge XXI veka // Voprosy istorii. 1996. № 4 .

18. Istoriya Dal'nego Vostoka $\mathrm{v}$ litsakh. Zabytye imena. Vyp. 1: St. i ocherki / Redkol.: I. G. Stryuchenko (otv. red.) i dr. Vladivostok: Dal'nauka, 1994. $182 \mathrm{~s}$.

19. Koval'chenko I. D. Teoretikometodologicheskie problemy istoricheskikh issledovanij. Zametki i razmyshleniya o novykh podkhodakh // Novaya i novejshaya istoriya. 1995. № 1.

20. Kocheshkov N. V. Ob itogakh konkursa: $\mathrm{K}$ voprosu o sozdanii novoj kontseptsii istoricheskogo protsessa na Dal'nem Vostoke Rossii 1917-1991 g. // Rossiya i ATR. 1995. № 2. S. 5-6.

21. Mandrik A. T. Na marksistskikh dogmakh...: Stroitel'stvo «gosudarstvennogo sotsializma» na Dal'nem Vostoke Rossii v 1920-1930-e gody XX stoletiya // Rossiya i ATR. 1995. № 2. S. 27-31.
22. Mukhachyov B. I. «Belye pyatna» Krasnogo oktyabrya // Rossiya i ATR. 1995. № 2. S. 21-26.

23. Mukhachyov B. I. Pravda istorii: Dal'nevostochnaya respublika i bor'ba $s$ interventsiej na Dal'nem Vostoke // Rossiya i ATR. 1992. № 1. S. 11-22.

24. Polyakov YU. A. Nashe nepredskazuemoe proshloe: Polemicheskie zametki. M.: AIRO-XX, 1995. $214 \mathrm{s.}$

25. Ryabchenko N. P. Rossiya, Dal'nij Vostok i «sotsializm» // Rossiya i ATR. 1995. № 2. S. 12-20.

26. Sukhin YU. I. Logikometodologicheskij aspekt leninskoj kontseptsii sotsializma // Lenin. Sotsializm. Sovremennost': Tez. dokl. nauch.-prak. konf. «Sotsializm: Istoriya, sovremennost' i budushhee». Preprint. Vladivostok, 1991. S. 9-11.

27. Trudy Instituta istorii, arkheologii i ehtnografii narodov Dal'nego Vostoka DVNTS AN SSSR. 1971-1985 gg. Vladivostok: DVNTS AN SSSR, 1986. $294 \mathrm{~s}$

28. Trudy Instituta istorii, arkheologii i ehtnografii narodov Dal'nego Vostoka DVO RAN. 1986-1995 gg.: Bibliogr. ukaz. Vladivostok: Dal'nauka, 1996. 204 s.

29. Trudy Instituta istorii, arkheologii i ehtnografii narodov Dal'nego Vostoka DVO RAN. 1996-2000 gg.: Bibliogr. ukaz. Vladivostok: Dal'nauka, 2001. 172 s.

30. Trudy Instituta istorii, arkheologii i ehtnografii narodov Dal'nego Vostoka DVO RAN. 2000-2005 gg.: Bibliogr. ukaz. Vladivostok: Dal'nauka, 2006. $212 \mathrm{~s}$.

31. Trudy Instituta istorii, arkheologii i ehtnografii narodov Dal'nego Vostoka DVO RAN. 2006-2010 gg.: Bibliogr. ukaz. Vladivostok: Dal'nauka, 2011. 288 s.

32. Trudy Instituta istorii, arkheologii i ehtnografii narodov Dal'nego Vostoka DVO RAN. 2011-2015 gg.: Bibliogr. ukaz. Vladivostok: Dal'nauka, 2017. 336 s. 